Animal, Poultry and Fish Production Research

Available online at http://zjar.journals.ekb.eg http:/www.journals.zu.edu.eg/journalDisplay.aspx?Journalld=1\&queryType=Master

\title{
EFFECT OF PARTIAL OR COMPLETE REPLACEMENT OF SOYBEAN MEAL WITH LEAF PROTEIN CONCENTRATE MEAL IN NILE TILAPIA DIETS ON GROWTH PERFORMANCE AND BLOOD CONSTITUENTS
}

\author{
Mohamed S. Abdel-Rahman ", A.A. Al-Sagheer, G.A. Abdel-Rahman and M.S. Ayyat \\ Anim. Prod. Dept., Fac. Agric., Zagazig Univ., Egypt
}

Received: 20/05/2020 ; Accepted: 28/06/2020

\begin{abstract}
The current trial was conducted to study the effects of partial replacement of soybean meal (SBM) with leaf protein concentrate mixture (LPCM) from carrot and sugar beet leaves in Nile tilapia diets on growth performance, body composition and blood biochemical parameters. Three diets were formulated by replacing 0,50 and $100 \%$ of protein from SBM with LPCM (control, LPCM50, and LPCM100, respectively). Each diet was fed to three replicate groups of fish (initial body weight: $5.03 \pm 0.01 \mathrm{~g}$ ) for 12 weeks. Results showed that dietary LPCM substitution significantly decreased final weight, weight gain, specific growth rate, and feed intake of juvenile tilapia. No significant differences in feed conversion ratio and survival rate were observed among the experimental groups. Condition factor significantly increased in fish groups LPCM50 and LPCM100 compared with those in control. Fish fed LPCM50 and LPCM100 diets had lower crude lipid content than the control group. Regarding all blood biochemical and hematological parameters, no significant differences were observed among all groups. However, the relative margin was increased by $12.83 \%$ in LPCM100 group, while decreased by $5.88 \%$ in fish group LPCM50 compared with the control one. These findings demonstrated that partial or complete replacement of SBM protein with LPCM has impaired growth performance of $O$. niloticus, without any negative effect on blood constituents. In addition, the relative margin was increased significantly in $O$. niloticus fed LPCM100 diet.
\end{abstract}

Key words: Leaf protein concentrate, Nile tilapia, growth performance, blood biochemistry.

\section{INTRODUCTION}

Global aquaculture production in 2016 included 80.0 million tonnes of food fish and 30.1 million tonnes of aquatic plants, as well as 37900 tonnes of non-food products (FAO, 2018). Aquaculture is considered one of the main sources to provide the animal protein for human consumption in the whole world (FAO, 2016). A major determinant of successful growth and intensification of aquaculture production is aqua feed. Feed comprises the major cost in fish production and accurate supply of the nutritional requirements increases the efficiency of production. Ideally, the nutrient requirements and nutrient concentration of a feedstuff should be expressed in units of availability so that least-cost formulations can optimize the nutrient requirements minimizing the cost of feeds or of production (Sklan et al., 2004).

Several plants contain appreciable quantity of protein with good amino acid profile that can be used during aqua feed formulation (Gatlin $\boldsymbol{e t}$ al., 2007; Azaza et al., 2008). Plant-based protein sources may be the only solution to reduce high feed costs in aquaculture (Hlophe et al., 2011). The results showed great variation in the degree of success for using plant protein in fish diets depending on the species of fish under culture, feeding strategy and the ingredients available (Gatlin et al., 2007; Koumi et al., 2009). Plant products contain huge amount protein, different amino acid and fatty acids

Corresponding author: Tel. : +201128375462

E-mail address: ensaades@yahoo.com 
which are not available in animal protein. In fish feed industry grasses, vegetables, aquatic weeds, plant's leaves, stems, seeds and seed extracts are commonly used (Mondal and Payra, 2015). The use of leaf protein concentrates as dietary feed ingredients has great potential because of the feasibility of producing good quality protein from tropical and subtropical plant leaves (Vinconneau, 1979). The leaf protein concentrate contains high crude protein $(48.9 \%)$ and crude fat $(14.5 \%)$. Apart from the relatively high mineral and protein contents, it has an amino acid profile which in most cases compares with those of fishmeal. Leaf protein concentrate has been reported to enhance growth rate when it replaced soybean (Agbede, 2000).

Therefore research into the utilization of plant protein ingredients in aquafeed will more likely continue. The present study aimed to investigate the effects of partial or complete replacing soybean meal with leaf protein concentrate in a formulated feed on the growth performance, carcass proximate and economic efficiency of Nile tilapia (Oreochromis niloticus).

\section{MATERIALS AND METHODS}

The present study was carried out at the Wet Laboratory of the Animal Production Department, Faculty of Agriculture, Zagazig University, Egypt. The experimental period lasted 84 days from May to August, 2019. In a complete randomized design, all fish were randomly distributed into 9 glass aquaria $\left(35 \times 70 \times 40 \mathrm{~cm}-0.074 \mathrm{~m}^{3}\right.$ of water) in 3 treatments (3 replicates per treatment). The first group fed the control diet (control; T1), the second group was fed on diet replaced $50 \%$ of soybean meal with $25 \%$ carrot leaf protein concentrate and $25 \%$ sugar beet leaf protein concentrate $(25 \%$ CLPC $+25 \%$ SLPC; T2) and the third group was fed on diet replaced $100 \%$ of soybean meal with $50 \%$ carrot leaf protein concentrate and $50 \%$ sugar beet leaf protein concentrate $(50 \%$ CLPC $+50 \%$ SLPC; T3). The test diets were formulated as shown in Table 1.

Healthy fingerlings; sex-reversed (all-male) of Nile tilapia (Oreochromis niloticus) provided by the Fish Hatchery of Central Laboratory for Aquaculture Research at Abbassa, Sharkia
Governorate, Egypt. One hundred and thirty five fingerlings (weighing approximately $5.02 \pm 0.019$ $\mathrm{g}$ after adaptation period for three weeks under normal laboratory conditions) were randomly distributed into the glass aquaria. The system installed in an environmental-controlled laboratory with a photoperiod of $12 \mathrm{hr}$., light and $12 \mathrm{hr}$., darkness. Continuous aeration was provided by an air blower. Fish were fed at the rate of $3 \%$ of live body weight and it offered two times at 8.00 and 15.00 hours. The fish in each aquarium were weighed biweekly, and the feed weight was adjusted after each fish weighing. About $25 \%$ of the water in the aquarium was daily replaced by aerated freshwater. Each aquarium was supplied with air pump to supply fish with oxygen. The glass aquariums were supplied with well-aerated and dechlorinated tap water from storage tank. Air was compressed to each aquarium via air stones by air pumps during the experimental period. The diet remains and fish wastes of each aquarium were removed by siphoning using plastic tube before the second daily feeding to further analysis and minimize leaching. Every second day, each aquarium was partially cleaned, including the fish feces and the water partially changed (about 50\%).

The experimental diets were analyzed to determine moisture, protein, lipid, fiber, and ash contents. Also, the proximate composition, including crude protein, crude fat, crude ash and moisture of body composition was determined using the standard procedures of AOAC (2005). Fish were weighed to the nearest $0.1 \mathrm{~g}$ at the beginning of the experiments and every 15 days and the amount of feed given was adjusted in accordance with the new measured biomass. Body weight gain was calculated by subtracting the two successive live weights at different experimental periods (weight gain $(\mathrm{g} / \mathrm{fish})=$ final weight-initial weight). Specific growth rate (SGR) was calculated according the following equation: $\mathrm{SGR}=[\ln$ (final fish weight $)-\ln$ (initial fish weight) $] \times 100 /$ period (day).

The proximate composition, including crude protein, crude fat, crude ash and moisture of body composition was determined using the standard procedures of AOAC (2005). At the end 
Zagazig J. Agric. Res., Vol. 47 No. (4) 2020

Table 1. Formulation and proximate chemical composition of trial diets

\begin{tabular}{|c|c|c|c|}
\hline Ingredient (\%) & Control (T1) & $50 \%$ LPCM (T2) & $100 \%$ LPCM (T3) \\
\hline Fish meal & 12 & 12 & 12 \\
\hline Soybean meal & 35 & 17 & 0 \\
\hline Corn grain & 22 & 21 & 19 \\
\hline Wheat bran & 20 & 20 & 20 \\
\hline Corn gluten & 6 & 7 & 7 \\
\hline Vegetable oil & 2 & 2 & 2 \\
\hline CLPC $^{1}$ & 0 & 8 & 15 \\
\hline SLPC $^{1}$ & 0 & 10 & 22 \\
\hline Dicalcium phosphate & 1 & 1 & 1 \\
\hline Vitamin mixture $^{2}$ & 1 & 1 & 1 \\
\hline Minerals mixture $^{3}$ & 1 & 1 & 1 \\
\hline \multicolumn{4}{|l|}{ Chemical composition (\%) } \\
\hline Crude protein & 32.19 & 32.00 & 32.05 \\
\hline Ether extract & 6.04 & 6.07 & 6.10 \\
\hline Crude fiber & 4.89 & 3.84 & 2.81 \\
\hline Nitrogen free extract & 42.49 & 41.06 & 39.48 \\
\hline Gross energy (kcal/kg) ${ }^{4}$ & 4136 & 4069 & 4010 \\
\hline Price per kg (LE) & 8.66 & 7.50 & 6.33 \\
\hline
\end{tabular}

1 LPCM, leaf protein concentrate mixture (LPCM) from carrot and sugar beet leaves

2 Each one $\mathrm{Kg}$ of mineral mixture contained: Zinc $1.23 \mathrm{~g}$, manganese $930 \mathrm{mg}$, Iron $630 \mathrm{mg}$, Copper $105 \mathrm{mg}$ and selenium $2.1 \mathrm{mg}$.

3 Each one Kg of vitamin mixture contained: Vitam. A 72000 IU, Vitam. B1 6 mg, Vitam. B3 12000 IU, Vitam. B6 9 mg, B12 $0.06 \mathrm{mg}$, Vitam. E $60 \mathrm{mg}$, Vitam. K $12 \mathrm{mg}$, Pantothenic acid $60 \mathrm{mg}$, Nicotinic acid $120 \mathrm{mg}$, Folic acid $6 \mathrm{mg}$, Biotin 0.3 $\mathrm{mg}$ and Choline chloride $3 \mathrm{mg}$.

4 Calculated according to NRC (1993).

of the feeding trial, blood samples were collected via caudal vein. Whole blood was collected in a small sterile vial having anticoagulant (EDTA). The collected samples were used to measure the hematological parameters including total red blood cells (RBCs), hemoglobin ( $\mathrm{Hb})$, hematocrit (HCT), mean cell volume (MCV), mean corpuscular hemoglobin concentration (MCHC), total leukocytes (WBC), and lymphocytes were evaluated according to Feldman et al. (2000). Other blood samples were collected without adding EDTA, centrifuged (SIGMA 2-3,
Osterode, Germany) at $3000 \mathrm{rpm}$ for $20 \mathrm{~min}$, and stored at $-20^{\circ} \mathrm{C}$ until analyses. The collected serum were used to measure biochemical parameters including serum total protein, albumin (Sundeman, 1964), creatinine, urea- $\mathrm{N}$ (Henery, 1974) and plasma transaminase enzymes AST; aspartate amino transferase and ALT; alanine amino transferase (Reitman and Frankel, 1957) were determined using the commercial kits from Diamond Diagnostics Company, Egypt. Fractionation of serum proteins was done using sodium dodecyl sulfatepolyacrylamide gel electrophoresis (SDS- 
PAGE) technique for determination of serum alpha $(\alpha)$, beta $(\beta)$ and gamma $(\gamma)$ globulins according to the technique described by Ornstein (1964). Serum cholesterol and triglycerides were determined according to the method of Kaplan et al. (1987) and Bucolo and David (1973), respectively. High-density lipoprotein cholesterol (HDL-C) concentration was carried out according to Vassault et al. (1986). Low-density lipoprotein cholesterol (LDL-C) and very low-density lipoprotein cholesterol (VLDL-C) concentrations were calculated according to Ahmadi et al. (2008).

Water quality control was measured biweekly analysis before replacing the water in the aquarium during the experimental period. All the water quality parameters were within the acceptable ranges for fish growth (Boyd, 1990). Water temperature was measured in each aquarium daily using a mercury thermometer of 0 to $100^{\circ} \mathrm{C}$ range. Dissolved oxygen was measured directly by using oxygen meter apparatus (XSI model 58, Yellow Spring Instrument Co., Yellow Springs, Ohio, USA). Ammonia $\left(\mathrm{NH}_{4}-\mathrm{N}\right.$ $\mathrm{mg} / \mathrm{l})$, Nitrate $\left(\mathrm{NO}_{3}-\mathrm{N} \mathrm{mg} / 1\right)$, Nitrite $\left(\mathrm{NO}_{2}-\right.$ $\mathrm{Nmg} / \mathrm{l}$ ) and $\mathrm{pH}$ were measured by using the Hach kit model HI 83205 (Multipurameter Bench Photometer, Hanna Instruments, Romania). Continuous aeration was provided by an air blower.

The economic assessment was determined according to the equation of Ayyat et al. (2018). Profit is the difference between the income from body gain and feed costs. Relative profit = survival rate $(\%) \times$ final margin. Assuming the rest of the other costs remains constant. The price of selling of one $\mathrm{kg}$ of fish was 25.0 LE (Egyptian pound equal to 0.064 US\$). The price of the diets was shown in Tables 1.

The data were statistically analyzed by a completely randomized design with SAS (2004) in relation to the following model: $Y_{i j}=\mu+T_{i}+$ $E_{i j}$. Where $\mu$ is the overall mean, $T_{i}$ is the fixed effect of $i^{\text {th }}$ treatments, and $E_{i j}$ is the random error. Differences between treatments were statistical tested by Duncan's multiple range test (Duncan, 1955).

\section{RESULTS AND DISCUSSION}

All tested water quality criteria were suitable for rearing Nile tilapia (O. niloticus) fingerlings. Water temperature, oxygen, $\mathrm{pH}$, ammonia and nitrite (overall mean) were $27.53^{\circ} \mathrm{C}, 7.07 \mathrm{mg} / \mathrm{l}$, $7.43 \mathrm{mg} / 1,0.087 \mathrm{mg} / \mathrm{l}$ and $0.114 \mathrm{mg} / \mathrm{l}$, respectively. Ranges of water quality parameters within the acceptable ranges required for normal growth of tilapia as mentioned by Boyd (1990).

Final body weight of Nile tilapia fish significantly $(\mathrm{P}<0.01)$ decreased as the replacement of soybean meal with the leaf protein concentrations. Final body weight decreased by 8.52 and $6.80 \%$ in fish group $25 \%$ CLPC $+25 \%$ SLPC (T2) and 50\% CLPC + 50\% SLPC (T3) when compared with the control group (Table 2 and Fig. 1). Daily body gain, specific growth rate and daily feed intake of Nile tilapia fish significantly $(\mathrm{P}<0.05$ or 0.01$)$ affected with the replacement of soybean meal with the leaf protein concentrations at 4-8 and 0-12 weeks of the experimental period, except at $0-4$ and $8-12$ weeks of the experimental period insignificantly affected (Table 2). The fish group fed diet replaced $50 \%$ of soybean meal with leaf protein (T2) recorded the lower daily body gain at 0-12 weeks than the other groups. When compared the experimental groups with the control group, daily body gain decreased by 11.17 and $9.04 \%$, respectively in fish group fed diets $25 \%$ CLPC + 25 SLPC and 50\% CLPC + 50\% SLPC, while the same trend for the specific growth rate were 8.52 and $6.80 \%$, respectively (Fig. 1). Feed conversion of Nile tilapia fish insignificantly affected with the replacement of soybean meal with the leaf protein concentrations at 8-12 and $0-12$ weeks of the experimental period, while at $0-4$ and 4-8 weeks significantly $(\mathrm{P}<0.05)$ affected (Table 2). Fish group fed the control $\operatorname{diet}(\mathrm{T} 1)$ or $50 \%$ CLPC $+50 \%$ SLPC (T3) recorded the best values of feed conversion, while fish fed $25 \%$ CLPC $+25 \%$ SLPC (T2) recorded the bad feed conversion ratio (Fig. 1). The obtained growth performance results may be indicated that Soybean meal can partially or completely replacement with leaf concentrate protein from carrot and sugar beet. The results of Paray et al. (2020) showed that the oak leaf 
Zagazig J. Agric. Res., Vol. 47 No. (4) 2020

Table 2. Growth performance of Nile tilapia as affected by dietary replacement of soybean meal protein by leaf protein concentrate mixture (LPCM) from carrot and sugar beet leaves

\begin{tabular}{|c|c|c|c|c|}
\hline Item & Control (T1) & $50 \%$ LPCM (T2) & $100 \%$ LPCM (T3) & Significant \\
\hline \multicolumn{5}{|l|}{ Body weight (g) at } \\
\hline Initial weight & $5.011 \pm 0.013$ & $5.027 \pm 0.008$ & $5.022 \pm 0.014$ & NS \\
\hline 4 Week & $7.238 \pm 0.373$ & $6.313 \pm 0.094$ & $6.282 \pm 0.214$ & NS \\
\hline 8 Week & $11.238 \pm 0.481$ & $11.548 \pm 0.123$ & $10.690 \pm 0.207$ & NS \\
\hline 12 Week & $20.821 \pm 0.417^{\mathrm{a}}$ & $19.047 \pm 0.104^{\mathrm{b}}$ & $19.405 \pm 0.167^{\mathrm{b}}$ & $* *$ \\
\hline \multicolumn{5}{|c|}{ Daily weight gain (g/day) at } \\
\hline 0-4 Week & $0.080 \pm 0.014$ & $0.046 \pm 0.004$ & $0.045 \pm 0.007$ & NS \\
\hline 4-8 Week & $0.143 \pm 0.008^{b}$ & $0.187 \pm 0.007^{\mathrm{a}}$ & $0.157 \pm 0.012^{\mathrm{ab}}$ & $*$ \\
\hline 8-12 Week & $0.342 \pm 0.031$ & $0.268 \pm 0.008$ & $0.311 \pm 0.008$ & NS \\
\hline 0-12 Week & $0.188 \pm 0.005^{\mathrm{a}}$ & $0.167 \pm 0.001^{\mathrm{b}}$ & $0.171 \pm 0.002^{b}$ & $* *$ \\
\hline \multicolumn{5}{|c|}{ Specific growth rate at } \\
\hline 0-4 Week & $1.303 \pm 0.194$ & $0.813 \pm 0.057$ & $0.796 \pm 0.111$ & NS \\
\hline 4-8 Week & $1.575 \pm 0.091^{\mathrm{b}}$ & $2.157 \pm 0.085^{\mathrm{a}}$ & $1.901 \pm 0.153^{b}$ & $*$ \\
\hline 8-12 Week & $2.207 \pm 0.214$ & $1.788 \pm 0.055$ & $2.130 \pm 0.068$ & NS \\
\hline 0-12 Week & $1.695 \pm 0.021^{\mathrm{a}}$ & $1.586 \pm 0.008^{\mathrm{b}}$ & $1.609 \pm 0.008^{b}$ & $* *$ \\
\hline \multicolumn{5}{|c|}{ Daily feed intake (g feed/day) at } \\
\hline 0-4 Week & $0.168 \pm 0.003$ & $0.164 \pm 0.002$ & $0.159 \pm 0.001$ & NS \\
\hline 4-8 Week & $0.247 \pm 0.013^{\mathrm{a}}$ & $0.214 \pm 0.002^{\mathrm{b}}$ & $0.208 \pm 0.004^{\mathrm{b}}$ & $*$ \\
\hline 8-12 Week & $0.406 \pm 0.009$ & $0.397 \pm 0.003$ & $0.381 \pm 0.004$ & NS \\
\hline 0-12 Week & $0.274 \pm 0.008^{\mathrm{a}}$ & $0.258 \pm 0.002^{\mathrm{ab}}$ & $0.250 \pm 0.002^{\mathrm{b}}$ & * \\
\hline \multicolumn{5}{|c|}{ Feed conversion ( $g$ feed/g gain) at } \\
\hline 0-4 Week & $1.182 \pm 0.065^{\mathrm{a}}$ & $0.878 \pm 0.026^{\mathrm{b}}$ & $1.024 \pm 0.076^{\mathrm{ab}}$ & * \\
\hline 4-8 Week & $1.739 \pm 0.127^{\mathrm{a}}$ & $1.149 \pm 0.045^{\mathrm{b}}$ & $1.335 \pm 0.104^{\mathrm{b}}$ & $*$ \\
\hline 8-12 Week & $1.209 \pm 0.133$ & $1.486 \pm 0.053$ & $1.227 \pm 0.042$ & NS \\
\hline 0-12 Week & $1.457 \pm 0.076$ & $1.548 \pm 0.022$ & $1.457 \pm 0.009$ & NS \\
\hline
\end{tabular}

Values in each row with different superscripts have significant differences $(\mathrm{p}<0.05)$.

$\mathrm{NS}=$ Not significant, $*=\mathrm{P}<0.05$, and $* *=\mathrm{P}<0.01$.

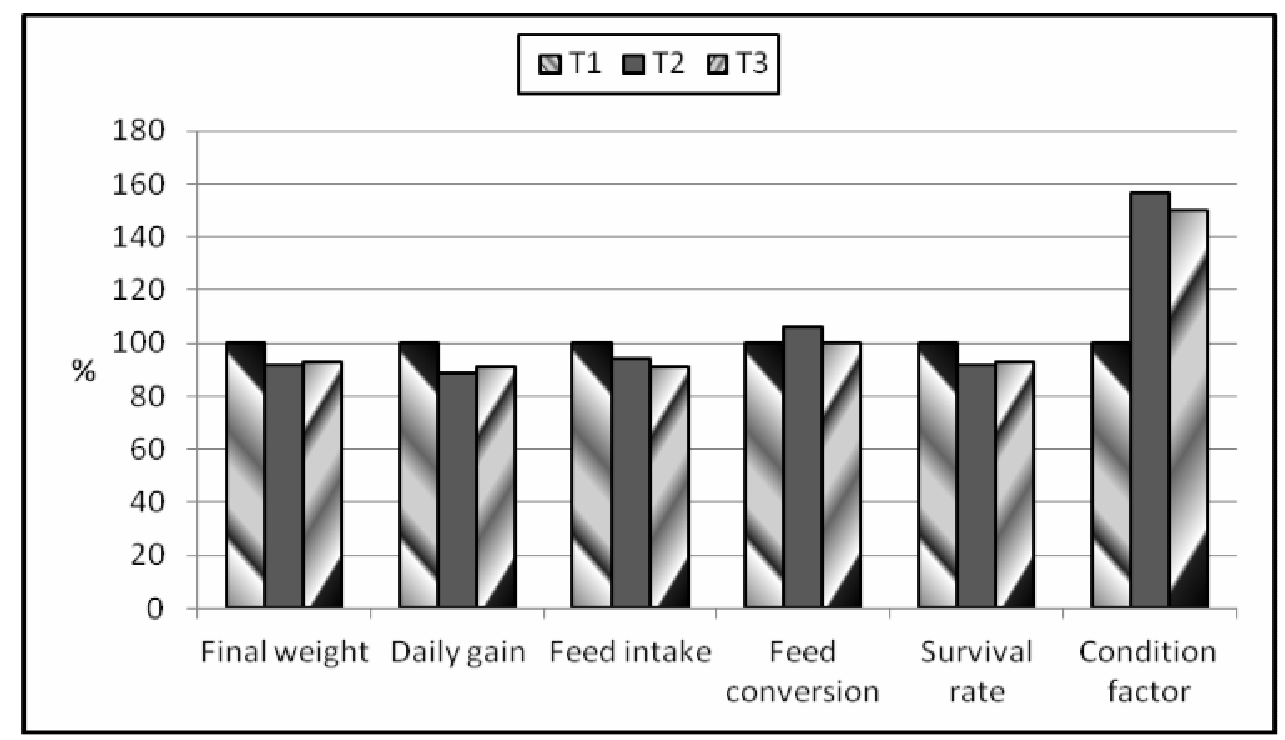

Fig. 1. Final body weight, daily gain, feed conversion and survival rate index of Nile tilapia fish as affected by substituting dietary soybean meal by leaf protein concentrations, when the values of the control group considered as $100 \%$ 
extract had no significant effects on the common carp fish growth performance. Also, the results of Osman et al. (1996) indicated that weight gain, specific growth rate, feed conversion ratio and protein utilization parameters were significantly increased by the higher percentage of dried or cooked leucaena leaf meal in tilapia diets.

In the experiment of Soares et al. (2001) Nile tilapia diets were formulated with 0.00 , 33.33, 66.67 and $100.00 \%$ levels of soybean meal protein replacement by the canola meal protein, corresponding to $0.00,24.50,49.00$, and $73.50 \%$ dietary canola meal inclusion in the diets. Feed gain ratio and protein efficiency rate were not affected by the treatments. It was concluded that canola meal can be included at $35.40 \%$ of diets, substituting $48.17 \%$ of soybean meal protein in diets for Nile tilapia in the growing phase. Da Silva et al. (2017) studied the replacement levels of 0,25, 50, 75 and $100 \%$ of soybean meal digestible protein by peanut meal for Nile tilapia diets. The feed conversion ratio was significantly affected when the soybean meal was totally replaced by peanut meal. The protein efficiency ratio, protein retention and whole-body protein content significantly decreased in fish fed diets containing peanut meal levels above $25 \%$ of peanut meal. Therefore, peanut meal can replace up to $25 \%$ of soybean meal without impairing juvenile Nile tilapia growth performance, feed efficiency, and body composition.

Survival rate of Nile tilapia insignificantly affected with the feed treatments. Condition factor significantly $(\mathrm{P}<0.01)$ increased as affected with the replacement of soybean meal with the leaf protein concentrations (Table 3 ). Condition factor increased by 56.47 and $49.96 \%$, respectively in fish group fed diets $25 \%$ CLPC + 25 SLPC and 50\% CLPC + 50\% SLPC when compared with the control group (Fig. 1).

Gupta and Tripathi (2017) indicated that better body condition is correlated with high values of condition factor and poor body condition is obtained when the values of condition factor is less.
Body crude protein and crude lipids significantly $(\mathrm{P}<0.01)$ decreased as affected with the replacement of soybean meal with the leaf protein concentrations (Table 3). El-Saidy and Saad (2011) find that up to $41.25 \%$ cottonseed meal can be used to replace $75 \%$ of soybean meal protein in diets for male Nile tilapia fingerlings without any adverse effects on the body composition.

Liver and kidney functions indicators, serum protein profile, lipid profile and hematological parameters of Nile tilapia insignificantly affected with the replacement of soybean meal with the leaf protein concentrations (Tables 4 and 5). El-Saidy and Saad (2011) find that up to $41.25 \%$ cottonseed meal can be used to replace $75 \%$ of soybean meal protein in diets for male Nile tilapia fingerlings without any adverse effects on the hematological indexes.

The economic visibility of Nile tilapia as affected by substituting dietary soybean meal by different levels of leaf protein concentrate from carrot or sugar beet are shown in Table 6. Feed cost of Nile tilapia decreased with the replacement of soybean meal with the leaf protein concentrations, while the return from body gain decreased. Replacement $100 \%$ of soybean meal with the leaf protein concentrates recorded the best final margin and relative margin than the other groups. When compared the experimental groups with the control group, the obtained results showed that the relative margin increased by $12.83 \%$ in fish group fed diets 50\% CLPC + 50 SLPC, while fish fed 25\% CLPC $+25 \%$ SLPC the relative margin decreased by $5.88 \%$ (Fig. 2 ).

In conclusion, this study represents the first approach to assess the effects of the replacement of SBM protein with LPCM in Nile tilapia diets. The findings proved that partial or complete replacement of SBM protein with LPCM has reduced fish growth, but did not have any adverse effects on feed utilization and blood biochemical parameters. However, fish fed LPCM100 diet showed higher final and relative margin than other treatments. 
Table 3. Survival rate, Condition factor and whole body chemical composition of Nile tilapia as affected dietary replacement of soybean meal protein by leaf protein concentrate mixture (LPCM) from carrot and sugar beet leaves

\begin{tabular}{lcccc}
\hline Item & Control (T1) & $\mathbf{5 0 \% ~ L P C M ~ ( T 2 ) ~}$ & $\mathbf{1 0 0 \% ~ L P C M ~ ( T 3 ) ~}$ & Significant \\
\hline Survival rate (\%) & $95.555 \pm 2.222$ & $93.333 \pm 0.000$ & $93.333 \pm 0.000$ & NS \\
Condition factor (\%) & $1.229 \pm 0.020^{\mathrm{b}}$ & $1.923 \pm 0.029^{\mathrm{a}}$ & $1.843 \pm 0.120^{\mathrm{a}}$ & $* *$ \\
Whole body composition & $(\%$ on dry matter basis) & & \\
Moisture & $74.513 \pm 0.723$ & $73.337 \pm 0.306$ & $73.813 \pm 0.252$ & NS \\
Crude protein & $56.303 \pm 0.356^{\mathrm{a}}$ & $55.253 \pm 0.184^{\mathrm{ab}}$ & $53.837 \pm 0.634^{\mathrm{b}}$ & $*$ \\
Crude lipid & $25.253 \pm 0.133^{\mathrm{a}}$ & $22.923 \pm 0.194^{\mathrm{b}}$ & $21.623 \pm 0.384^{\mathrm{c}}$ & $* *$ \\
Ash & $17.453 \pm 0.668$ & $16.817 \pm 0.176$ & $18.017 \pm 0.303$ & $\mathrm{NS}$ \\
\hline
\end{tabular}

Values in each row with different superscripts have significant differences $(\mathrm{p}<.05)$.

NS $=$ Not significant, $*=\mathrm{P}<0.05$ and $* *=\mathrm{P}<0.01$.

Table 4. Blood biochemical of Nile tilapia as affected by dietary replacement of soybean meal protein by leaf protein concentrate mixture (LPCM) from carrot and sugar beet leaves

\begin{tabular}{lcccc}
\hline Item & Control (T1) & $\mathbf{5 0 \% ~ L P C M ~ ( T 2 ) ~}$ & $\mathbf{1 0 0 \% ~ L P C M ~ ( T 3 ) ~}$ & Significant \\
\hline Creatinine (mg/dl) & $1.070 \pm 0.021$ & $1.030 \pm 0.026$ & $1.037 \pm 0.057$ & NS \\
Urea (mg/dl) & $16.767 \pm 0.219$ & $16.033 \pm 0.788$ & $16.400 \pm 1.069$ & NS \\
ALT (U/L) & $16.567 \pm 0.657$ & $16.267 \pm 0.549$ & $16.900 \pm 0.981$ & NS \\
AST (U/L) & $29.567 \pm 1.277$ & $29.200 \pm 1.193$ & $29.433 \pm 0.696$ & NS \\
Total protein (g/dl) & $5.867 \pm 0.233$ & $5.800 \pm 0.252$ & $5.800 \pm 0.173$ & NS \\
Albumin (g/dl) & $2.930 \pm 0.125$ & $2.903 \pm 0.124$ & $2.877 \pm 0.118$ & NS \\
$\boldsymbol{\alpha 1}$ glob (g/dl) & $1.340 \pm 0.051$ & $1.223 \pm 0.057$ & $1.210 \pm 0.087$ & NS \\
$\boldsymbol{\alpha 2}$ glob (g/dl) & $1.577 \pm 0.067$ & $1.270 \pm 0.173$ & $1.397 \pm 0.151$ & NS \\
$\boldsymbol{\beta}$ glob (g/dl) & $1.000 \pm 0.026$ & $0.973 \pm 0.038$ & $1.010 \pm 0.050$ & NS \\
$\boldsymbol{\gamma}$ glob (g/dl) & $1.240 \pm 0.231$ & $1.163 \pm 0.113$ & $1.073 \pm 0.052$ & NS \\
Total glycerides (g/dl) & $109.000 \pm 1.732$ & $106.333 \pm 2.963$ & $106.333 \pm 1.453$ & NS \\
Cholesterol (g/dl) & $182.667 \pm 12.991$ & $168.667 \pm 11.724$ & $161.333 \pm 3.667$ & NS \\
HDL-C (g/dl) & $41.000 \pm 1.528$ & $40.000 \pm 1.528$ & $40.667 \pm 1.856$ & NS \\
LDL-C (g/dl) & $125.867 \pm 2.258$ & $125.067 \pm 4.570$ & $122.200 \pm 5.147$ & NS \\
VLDL-C (g/dl) & $9.133 \pm 0.406$ & $9.100 \pm 0.351$ & $9.167 \pm 0.240$ & NS \\
\hline
\end{tabular}

$\mathrm{NS}=$ Not significant 
Table 5. Hematological parameters of Nile tilapia as affected by dietary replacement of soybean meal protein by leaf protein concentrate mixture (LPCM) from carrot and sugar beet leaves

\begin{tabular}{lcccc}
\hline Item & Control (T1) & $\mathbf{5 0 \%}$ LPCM (T2) & $\mathbf{1 0 0 \% ~ L P C M ~ ( T 3 ) ~}$ & Significant \\
\hline RBCs $\left(\mathbf{1 0}^{\mathbf{6}} \times \boldsymbol{\mu L}\right)$ & $3.300 \pm 0.138$ & $3.290 \pm 0.135$ & $3.233 \pm 0.073$ & NS \\
Hb (g/dL) & $10.900 \pm 0.153$ & $10.767 \pm 0.517$ & $10.633 \pm 0.176$ & NS \\
HCT (\%) & $36.667 \pm 1.856$ & $36.333 \pm 0.667$ & $36.000 \pm 1.528$ & NS \\
MCV (fL) & $106.730 \pm 0.038$ & $103.677 \pm 3.243$ & $105.143 \pm 1.672$ & NS \\
MCHC (g/dL) & $31.873 \pm 1.219$ & $29.290 \pm 2.095$ & $31.320 \pm 1.913$ & NS \\
WBCs $\left(\mathbf{1 0}^{\mathbf{5}} \times \boldsymbol{\mu L}\right)$ & $5.620 \pm 0.114$ & $5.627 \pm 0.589$ & $5.027 \pm 0.251$ & NS \\
Lymphocyte $\left(\mathbf{1 0}^{\mathbf{5}} \times \boldsymbol{\mu L}\right)$ & $3.237 \pm 0.091$ & $3.263 \pm 0.520$ & $2.730 \pm 0.394$ & NS \\
\hline
\end{tabular}

$\mathrm{NS}=$ Not significant

Table 6. Economic visibility of Nile tilapia as affected by leaf protein concentrate mixture (LPCM) from carrot and sugar beet leaves.

\begin{tabular}{lccc}
\hline Item & Control (T1) & $\mathbf{5 0 \% ~ L P C M ~ ( T 2 ) ~}$ & $\mathbf{1 0 0 \% ~ L P C M ~ ( T 3 ) ~}$ \\
\hline Feed cost (LE/fish) & 0.199 & 0.163 & 0.133 \\
Return from gain (LE/fish) & 0.395 & 0.351 & 0.359 \\
Final margin (LE/fish) & 0.195 & 0.188 & 0.226 \\
Relative margin (LE/fish) & 0.187 & 0.176 & 0.211 \\
\hline
\end{tabular}

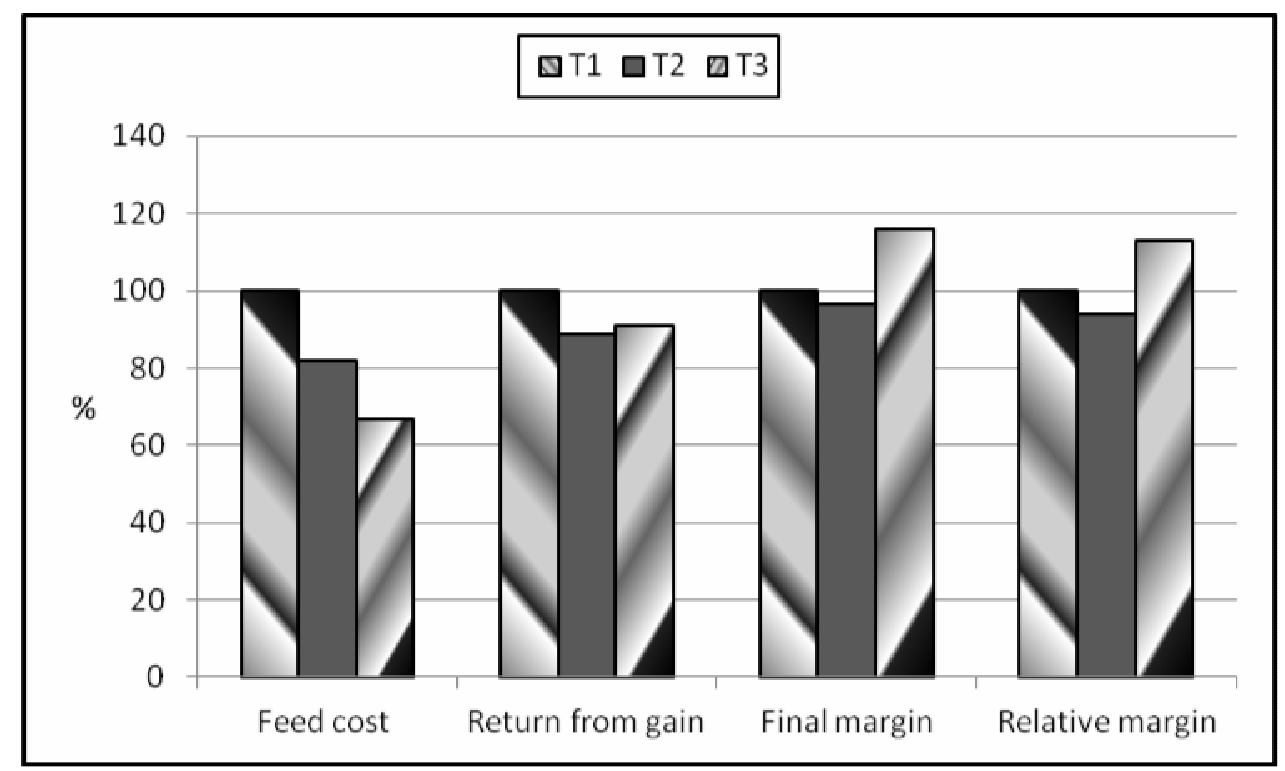

Fig. 2. The economic assessment index of Nile tilapia fish as affected by substituting dietary soybean meal by leaf protein concentrations, when the values of the control group considered as $100 \%$ 


\section{REFERENCES}

Agbede, J.O. (2000). Biochemical composition and nutritive quality of the seeds and leaf protein concentrates from underutilized tree and herbaceous legumes. Ph.D. Thesis, Federal Univ. Technol., Akure, Nigeria.

Ahmadi, S.A., M.A. Boroumand, M.K. Gouhari, P. Tajik and S.M. Dibaj (2008). The impact of low serum triglyceride on LDLcholesterol estimation.

AOAC (2005). Official Methods of Analysis Chemists $18^{\text {th }}$ Ed. Edited by Dr. William Horwitz and Dr. George W. Latimer, Jr., AOAC Int., Washington DC, USA.

Ayyat, M.S., A.M.N. Ayyat, A.A. Al-Sagheer and A.E.A.M. El-Hais (2018). Effect of some safe feed additives on growth performance, blood biochemistry, and bioaccumulation of aflatoxin residues of Nile tilapia fed aflatoxin- $\mathrm{B}_{1}$ contaminated diet. Aquac., 495: $27-34$.

Azaza, M.S., F. Mensi, J. Ksouri, M.N. Dhraïef, A. Abdelmouleh, B. Brini and M.M. Kraïem (2008). Growth of Nile tilapia (Oreochromis niloticus $\mathrm{L}$.) fed with diets containing graded levels of green algae ulva meal (Ulva rigida) reared in geothermal waters of southern Tunisia. J. Appl. Ichthyol., 24: 202-207.

Boyd, C.E. (1990). Water quality in ponds for aquaculture. Bermingham Publishing Co., Bermingham, Alabama, USA.

Bucolo, G. adn H. David (1973). Quantitative determination of serum triglycerides by the use of enzymes Clinical Chemistry, 19: 476482.

Da Silva, R.L., F.M. Damasceno, M. Karina, H.R. Rocha, M.P. Sartori, M.M. Barros and L.E. Pezzato (2017). Replacement of soybean meal by peanut meal in diets for juvenile Nile tilapia, Oreochromis niloticus. Latin Ame. J. Aquatic Res., 45 (5): 1044-1053.

Duncan, D.B. (1955). Multiple Ranges and Multiple F-test. Biometrics, 11: 1-42.

El-Saidy, D.M.S.A. and A.S. Saad (2011). Effects of partial and complete replacement of soybean meal with cottonseed meal on growth, feed utilization and haematological indexes for mono-sex male Nile tilapia, Oreochromis niloticus (L.) fingerlings. Aquac. Res., 42: 351-359.

FAO (2016). The State of World. Fisheries and Aquaculture. Fisheries and Aquaculture Department, Food and Agriculture Organization of the United Nations, Rome, 200.

FAO (2018). The State of World. Fisheries and Aquaculture. Fisheries and Aquaculture Department, Food and Agriculture Organization of the United Nations, Rome, 210.

Feldman, B.F., J.G. Zinkl and N.C. Jain (2000). Schalm's Veterinary Hematology, $5^{\text {th }}$ Ed. Lippincott, London, 1219-1924.

Gatlin, D.M., F.T. Barrows, P. Brown, K. Dabrowski, T. Gibson, K. Gaylord, T.C. Gaylord, R.W. Hardy, E. Herman, G. Hu, A. Krogdahl, R. Nelson, K. Overturf, M. Rust, W. Sealey, D. Stoneberg and E.J. Souza (2007). Expanding the utilization of sustainable plant products in aquafeeds: a review. Aquac. Res., 38: 551-579.

Gupta, D. and M. Tripathi (2017). Length-weight relationships and condition factors of five cyprinidae species (Subfamily-Barbinae) from three diverse rivers of Uttar Pradesh, India. Int. J. Fisheries and Aquatic Studies, 5 (2): 594-598.

Henery, R.J. (1974). Clinical Chemistry, Principles and Technique, $2^{\text {nd }} E d$. Harper and Row, New York.

Hlophe, S.N., N.A.G. Moyo and J.R. Sara (2011). Use of kikuyu grass as a fishmeal substitute in practical diets for Tilapia rendalli. Asian J. Anim. And Vet. Adv., 6: 1076-1083.

Kaplan, J.R., S.B. Manuck, M.R. Adams, K.W. Weingand and T.B. Clarkson (1987). Inhibition of coronary atherosclerosis by propranolol in behaviorally predisposed monkeys fed an atherogenic diet Circulation, 76: $1364-1372$

Koumi, A.R., B.C. Atse and L.P. Kouame (2009). Utilization of soya protein as an alternative protein source in Oreochromis 
niloticus diet: growth performance, feed utilization, proximate composition and organoleptic characteristics. Afr. J. Biotechnol., 8: 91-97.

Mondal, K. and P. Payra (2015). A review on use of plant protein sources in diets for fish feed formulation. J. Int. Acad. Res. Multidisciplinary, 3 (5): 257-264.

NRC (1993). Nutrient Requirements of Fish. National Academy Press. Washington DC.

Ornstein, L. (1964). Disc electrophoresis. 1. background and theory Annals of the New York Acad. Sci., 121:321-349.

Osman, M.F., A.E. Omar and A.M. Nour (1996). The use of leucaena leaf meal in feeding Nile tilapia. Aquac. Int., 4: 9-18.

Paray, B.A., S.M. Hoseini, S.H. Hoseinifar and H.V. Doan (2020). Effects of dietary oak (Quercus castaneifolia) leaf extract on growth, antioxidant, and immune characteristics and responses to crowding stress in common carp (Cyprinus carpio). Aquac., 524: 735276.

Reitman, S. and S. Frankel (1957). A colorimetric method for the determination of serum glutamic oxalacetic and glutamic pyruvic transaminases. Ame. J. Clin. Pathol., 28: 56-63.
SAS (2004). SAS Institute Inc., Cary, NC, USA. NOTE: SAS Proprietary Software Version 9.00 (TS M0).

Sklan, D., T. Prag and I. Lupatsch (2004). Apparent digestibility coefficients of feed ingredients and their prediction in diets for tilapia Oreochromis niloticus x Oreochromis aureus (Teleostei, Cichlidae) Aquac. Res., 35: 358-364.

Soares, C.M., C. Hayashi, A.C.E.A. De Faria and W.M. Furuya (2001). Replacement of soybean meal protein by canola meal protein in diets for Nile tilapia (Oreochromis niloticus) in the growing phase. Revista Brasileira de Zootecnia, 30 (4): 1172-1177.

Sundeman, M.F.W. (1964). Studies of the serum proteins. Ame. J. Clin. Path, 1-21.

Vassault, A., D. Grafmeyer, C. Naudin, G. Dumont, M. Bailly, J. Henny and P. Georges (1986). Protocole de validation de techniques. Ann. Biol. Clin., 44 (686): 45.

Vinconneau, H.F. (1979). Processing of leaf proteins into food ingredients. J. Ame. Oil Chemists' Soc., 56: 469-470.

\section{تأثير الإستبدال الجزئي أو الكلى لكسب فول الصويا ببروتين الأوراق المركز فى علاثق البلطى النيلى على أداء النمو ومكونات المونيات الأور \\ محمد سعد عبدالرحمن - أدهم عبدالله الصغير - جمال الدين على عبدالرحمن - محمد صلاح الدين عياط

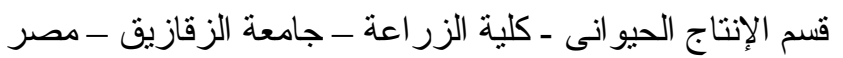

أجريت التجربة الحالية لار اسة تأثير الإحلال الجزئى أو الكلى لبروتين كسب فول الصويا بمخلوط مركز بروتين أوراق

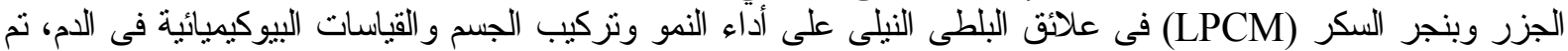

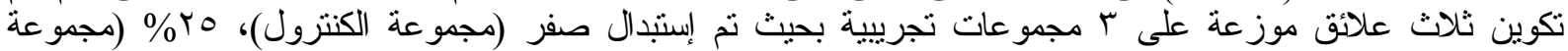

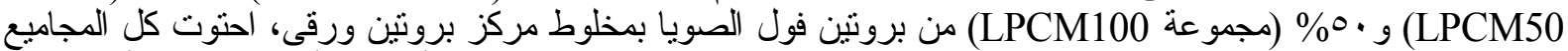

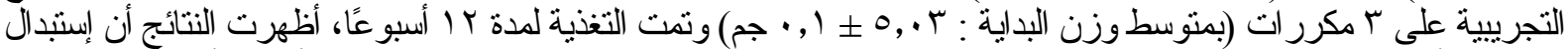
LPCM

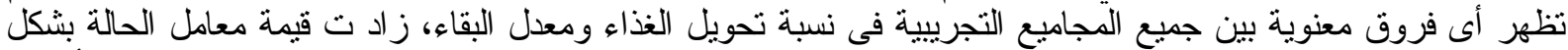

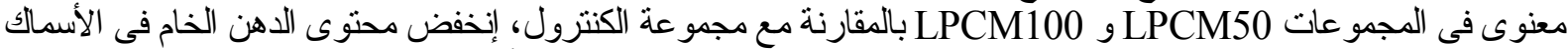

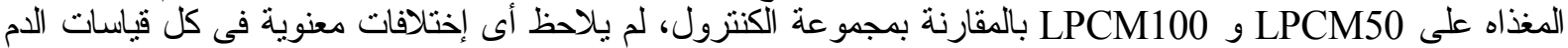

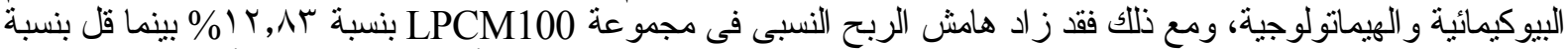

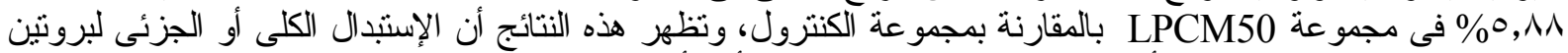

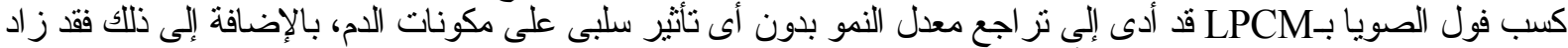

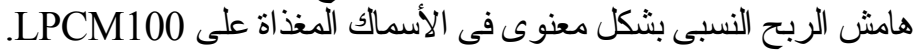

\section{أستاذ تغذية الأسماك بالمعمل المركزي لبحوث الأسماك بالعباسة. أستاذ فسيولوجي الأسماك ــ كلية الزر اعة بالإسماعيلية لإلية - جامعة قناة السويس.}

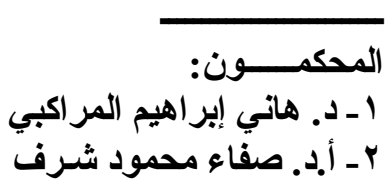

